\title{
VISUALISASI PERILAKU PENGENDARA SEPEDA MOTOR \\ SEBAGAI BENTUK CRIME IN EVERYDAY LIFE \\ ANALISIS CULTURAL CRIMINOLOGY
}

\author{
Neri Widya Ramailis
}

\begin{abstract}
The phenomenon of traffic violations made by motorcyclists on the road is a pattern of behavior that is accustomed habit, done repeatedly and happen everyday, so as to for man aberrant culture. Then, in another case of traffic violation phenomenon is also seen as a condition of demoralization, which is interpreted as a form of the decrease to values, morality and norms in society. Where, in this case the people familiar with the rules and laws that apply, however, the rules are not well practiced in everyday life. This thesis tries to explain how cultural criminology see motorcyclists behavioral phenomena in everyday life dimension in crime and crime as culture. The method used in this research is a visual analyst criminology developed by Cecil E. Greek to display an image/photo related traffic offenses committed motorcyclists. The conclusion of this thesis is the behavior of motorcyclists present in this case as a form of crime phenomena in everyday life (crime in everyday life), and the phenomenon of crime and culture (culture as crime).
\end{abstract}

Keywords: Motorcycle Rider Behaviour, Crime in Everyday Life, Crime as Culture, Cultural Criminology.

\begin{abstract}
ABSTRAK
Fenomena pelanggaran berlalulintas yang dilakukan oleh pengendara sepeda motor di jalan adalah pola perilaku kebiasaan, dilakukan berulang-ulang dan berlangsung setiap hari, sehingga untuk menjadi budaya menyimpang. Kemudian, dalam kasus lain dari fenomena pelanggaran lalu lintas juga terlihat sebagai suatu kondisi demoralisasi, yang diartikan sebagai bentuk penurunan nilai-nilai, moralitas dan norma-norma dalam masyarakat. Dimana, dalam hal ini orang yang akrab dengan aturan dan hukum yang berlaku, namun, aturan tidak baik dipraktekkan dalam kehidupan sehari-hari. Thesis ini mencoba untuk menjelaskan bagaimana kriminologi budaya melihat perilaku pengendara sepeda motor sebagai dimensi kehidupan fenomena setiap hari dalam kejahatan dan kejahatan sebagai budaya. Metode yang digunakan dalam penelitian ini adalah kriminologi visualanalyst dikembangkan oleh Cécile. Digunakan untuk menampilkan gambar / pengendara sepeda motor berkaitan pelanggaran lalu lintas yang dilakukan. Kesimpulan dari penelitian ini adalah perilaku pengendara sepeda motor hadir dalam ini bentuk fenomena kejahatan di kehidupan sehari-hari (crime in everyday), dan fenomena kejahatan dan budaya (budaya sebagai kejahatan).
\end{abstract}

Kata kunci : Perilaku Pengendara Sepeda Motor, Crimein everyday life, Crime as Culture, Cultural Criminology.

\section{PENDAHULUAN}

Tingginya arus lalu lintas kendaraan bermotor di jalanan ibukota khususnya wilayah Jakarta menyebabkan kondisi kemacetan semakin parah. Tidak heran, jika setiap hari di daerah Jakarta banyak ruas jalan berpotensi untuk terjadinya aksi pelanggaran lalu lintas. Selain itu, rendahnya kesadaran pengguna jalan, khususnya pengendara sepeda motor dalam menerapkan budaya tertib berlalu lintas membuat kondisi di jalan raya semakin buruk dan tidak teratur.

Data dari TMC Polda Metro Jaya menunjukkan, ada beberapa titik yang dimanfaatkan para pengendara sepeda motor untuk berlaku curang, dan mengambil jalan pintas dalam berkendara. Berikut sejumlah titik lokasi yang berpotensi setiap hari terjadinya pelanggaran lalu lintas di daerah Jakarta. Pertama, di depan pintu 1 Taman Mini Indonesia Indah. Kedua, di depan PGC Cililitan Jakarta Timur. Ketiga, di dekat rel Kereta Api Ulujami Pesanggrahan Jakarta Selatan. Keempat, di Jl.Ciledug Raya Jakarta Selatan. Kelima, di wilayah Kembangan Jakarta Barat. Keenam, di Jl.KH Mas Mansyur Tanah Abang. Ketujuh, di Jl.Ranco Tanjung Barat Jakarta Selatan. Kedelapan, di Jl. Yos Sudarso (Tl Permai). Kesembilan, di kawasan Pasar Blok A Kebayoran Baru Jakarta Selatan. Kesepuluh, di pinggir tol Jl. Pejuangan menuju RS Siloam Jakarta Barat. Kesebelas, di Jl. Lenteng Agung 
Jakarta Selatan. Dan yang terakhir, di Jl.Warung Jati Barat Raya Jakarta Selatan (http://news.detik.com/read/2014/05/14).
Berikut ini, beberapa gambaran atau visualisasi perilaku pengendara sepeda motor yang melakukan pelanggaran lalu lintas di sebagian wilayah Jakarta:

Tabel 1.1. Visualisasi Perilaku Pengendara Sepeda Motor

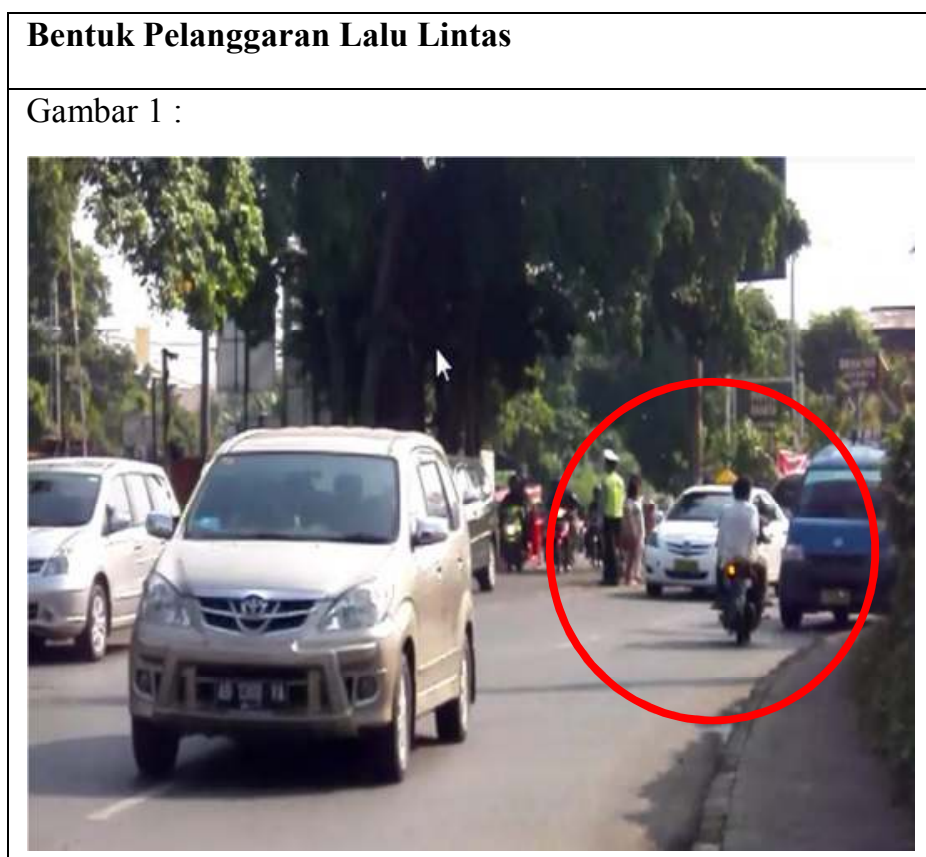

Penjelasan : Terlihat pengendara sepeda motor melawan arus dari arah jalan raya Depok menuju jalan raya Lenteng Agung dan ditengah jalan terlihat seorang polisi lalu lintas yang sedang bertugas menertibkan jalan raya.

\section{Gambar 2 :}

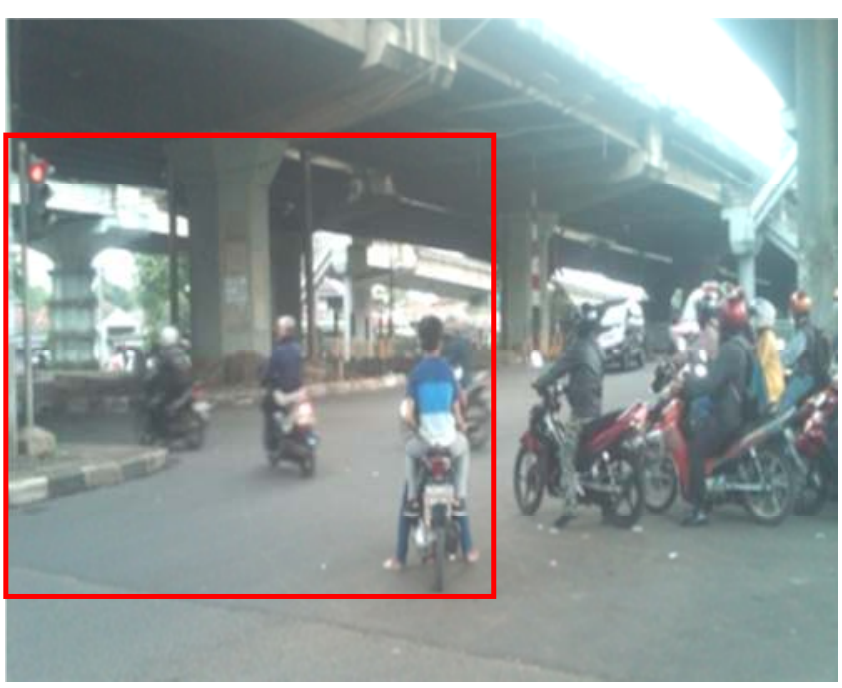

Penjelasan : Terlihat beberapa pengendara sepeda motor menerobos lampu merah, kemudian dari arah samping jalan terlihat dua orang pengendara sepeda motor yang tidak memakai helm.

\section{Tempat}

Lokasi kejadian: Di Jl.Gardu, dari arah jalan raya Depok menuju jalan raya Lenteng Agung.

Waktu kejadian: 25 Juni 2014, Jam

Lokasi kejadian: Di bawah flyover Tanjung Barat dari arah Pasar Minggu.

Waktu kejadian: 06 mei 2014 


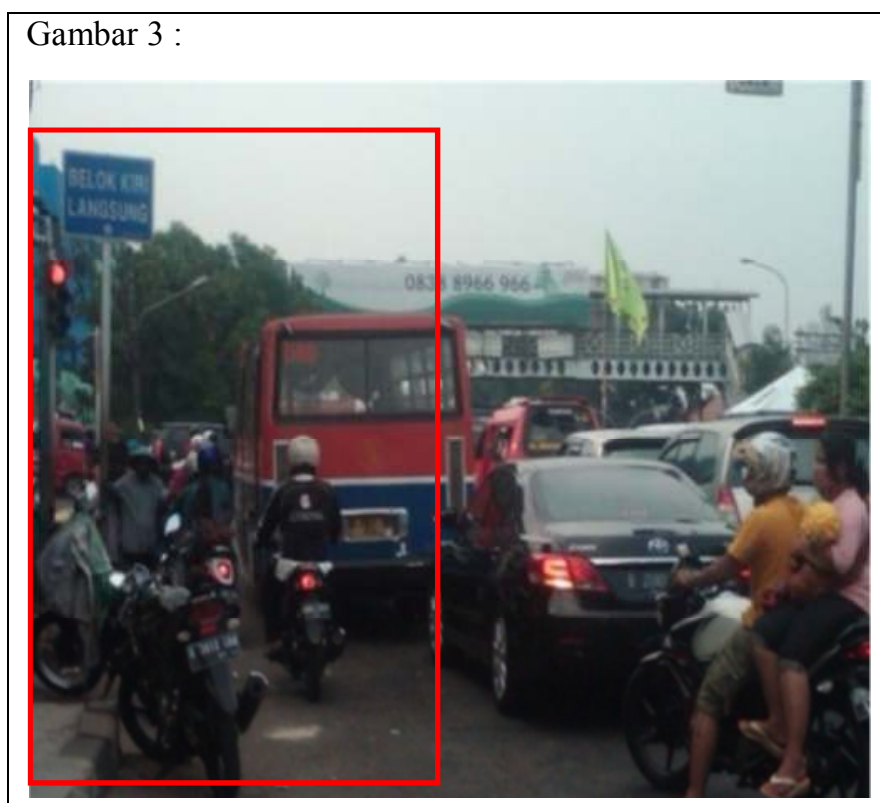

Lokasi kejadian: Lampu merah depan stasiun Comuter line Pasar Minggu.

Waktu kejadian: 10 mei 2014

Penjelasan : Terlihat pengendara sepeda motor dan mobil memenuhi ruas jalan raya, sehingga rambu-rambu yang berwarna biru bertuliskan belok kiri langsung tidak berlaku bagi pengendara yang ingin melanjutkan perjalanan ke arah kiri, karena dari arah depan jalan sudah dipenuhi oleh pengendara sepeda motor lainnya, mobil dan bus angkutan umum yang selalu menimbulkan kemacetan di jalanan.

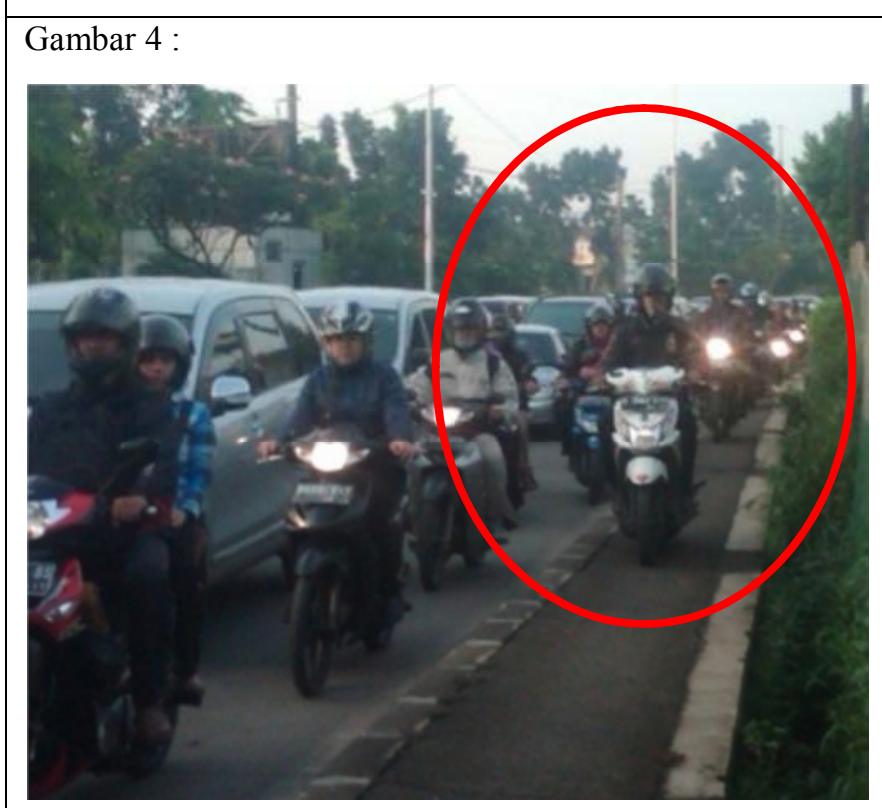

Penjelasan : Terlihat jelas dengan ramai pengendara sepeda motor menaiki jalan trotoar yang seharusnya diperuntukkan untuk pejalan kaki.

\section{Lokasi kejadian: Jalan raya Lenteng Agung menuju arah stasiun Comuter line Tanjung Barat.}

Waktu kejadian: 22 mei 2014 


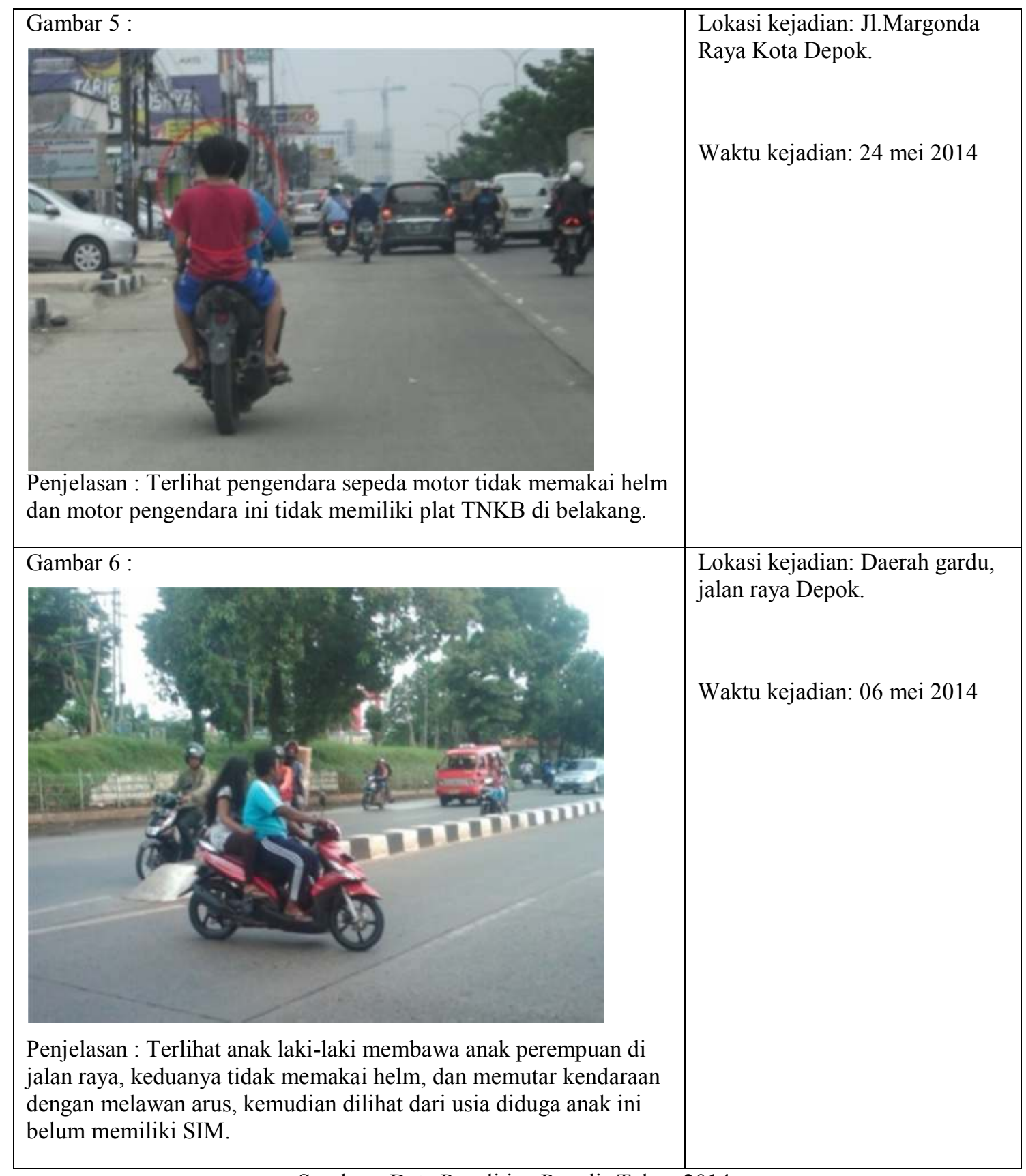

Sumber : Data Penelitian Penulis Tahun 2014.

Dari beberapa data visualisasi yang telah ditampilkan sebelumnya, hal ini merupakan salah satu potret dan gambaran betapa buruknya kondisi jalanan di Indonesia khususnya daerah Jakarta, sehingga di setiap ruas jalan selalu ditemukan perilaku pengendara sepeda motor yang tidak disiplin dalam berkendara, seperti memutar arah kendaraan di sembarang tempat dan bukan pada jalur yang tepat, melawan arus lalu lintas, menerobos lampu merah, dan lain sebagainya.
Berbagai macam bentuk perilaku dan pelanggaran yang dilakukan pengendara sepeda motor terjadi setiap hari di jalan raya. Fenomena tersebut hadir sebagai bentuk kejahatan dan budaya (crime as culture) dalam kehidupan sehari-hari. Dalam kajian kriminologi fenomena ini dikenal dengan istilah crime in everyday life

Menurut Mustofa (2010:197) kejahatan dalam kehidupan sehari-hari (everyday life crimes) tersebut berada pada kawasan abu-abu, berada antara tindakan yang tidak legal atau 
tidak bermoral. Masuk dalam kategori ini adalah menerobos lampu lalu lintas yang berwarna merah, mengendarai kendaraan dengan melawan arus, menghindari pembayaran pajak, klaim asuransi tidak jujur, yang tidak selalu merupakan tindakan yang secara yuridis salah. Tindakan tersebut lebih sering dikategorikan sebagai tidak bermoral atau tidak jujur baik oleh pelaku maupun korbannya.

Fenomena perilaku pengendara sepeda motor yang tidak tertib di jalan raya ini juga dilihat sebagai suatu bentuk kebiasaan yang dibiasakan dan secara terus-menerus dilakukan, sehingga orang dengan semena-mena melanggar peraturan.Hal demikian juga tidak lepas dari lemahnya penegakan hukum terhadap pelaku pelanggar aturan lalu lintas. Sebagai contoh perilaku pengendara sepeda motor yang menerobos lampu merah dan melawan arus lalu lintas, seharusnya penegak hukum dalam hal ini polisi lalu lintas tegas dalam memberikan sanksi terhadap mereka yang tidak taat pada peraturan. Akan tetapi, permasalahan ini tidak dapat sepenuhnya dilihat dalam perspektif penegakan hukum saja, karena fenomena tersebut berkaitan dengan permasalahan perilaku masyarakat, dimana rusaknya moralitas para pengendara sepeda motor.

Kebiasaan tidak disiplin dalam berkendara merupakan perilaku manusia yang mengindikasikan telah terjadinya penurunan kemampuan masyarakat mengatur individu. Anggota masyarakat beranggapan bahwa fenomena ini sebagai hal yang telah biasa terjadi dalam kehidupan sehari-hari. Akan tetapi, tulisan ini melihat bahwa fenomena tersebut merupakan wujud dari praktek budaya yang menyimpang terjadi setiap hari di jalan raya Jakarta.

Fenomena ini juga dapat dijelaskan melalui perspektif kriminologi budaya (cultural criminology). Menurut Jeff Ferrell, dalam karyanya "Culture, Crime, and Cultural Criminology", menjelaskan adanya hubungan antara apa yang disebut sebagai budaya, kejahatan dan penyimpangan, sehingga muncul konsep kriminologi budaya yang merupakan usaha untuk menunjukkan dasar persamaan antara kebudayaan dan praktik kejahatan dalam masyarakat, yaitu antara tingkah laku kolektif tentang perumpamaan, gaya, makna simbolik dengan rumusan legal dan rumusan politis penguasa yang menyebutkannya sebagai kejahatan atau penyimpangan (Mustofa, 2010: 173).
Merujuk pada tulisan di atas, yakni perilaku pengendara sepeda motor yang tidak tertib dan tidak disiplin dalam berkendara dilihat sebagai bentuk fenomena kejahatan dalam kehidupan sehari-hari (crime in everyday life), dan dalam kajian kriminologi budaya dilihat sebagai bentuk kejahatan dan budaya (crime as culture). Dimana dalam hal ini, terdapat dua dimensi yang saling berhubungan antara individu (pelaku kejahatan/penyimpangan) dan perilaku yang dimunculkan oleh individu, sehingga membentuk sebuah budaya menyimpang.

Di dalam penelitian ini, penulis membahas visualisasi perilaku pengendara sepeda motor dilihat sebagai bentuk kejahatan dalam kehidupan sehari-hari (crime in everyday life) dengan menggunakan kajian cultural criminology yang berparadigma Post-Modern Criminology. Terlebih dahulu, penulis akan membahas beberapa kepustakaan terkait dengan Post-Modern Criminology dan Cultural Criminology

\section{PEMBAHASAN}

\section{Kriminologi Postmodern dan Cultural Criminology}

Aliran pemikiran kriminologi post-modern pada dasarnya merupakan otokritik terhadap aliran pemikiran kriminologi kritis. Artinya bahwa aliran pemikiran post-modern masih merupakan bagian dari pemikiran kritis. Isi otokritik yang dilakukan terutama adalah bahwa aliran pemikiran kritis melakukan politisasi kejahatan. Masalah kejahatan hanya dikaitkan dengan ambisi penguasa untuk mempertahankan kekuasaannya, dan kejahatan hanya diartikan sebagai tindakan yang bertujuan mendongkel kekuasaan (Mustofa, 2010 : 175).

Di dalam aliran pemikiran post-modern criminology terdapat beberapa aliran pemikiran yang menjelaskan tentang aliran pemikiran kriminologi realis, kriminologi feminis, kriminologi konstitutif (constitutive criminology), dan aliran pemikiran kriminologi budaya (cultural criminology).

Adapun penjelasan lebih rinci mengenai konsep kriminologi budaya pada tulisan ini adalah suatu analisa hubungan antara kebudayaan dan kejahatan. Di satu pihak kejahatan dapat merupakan kebudayaan, di pihak lain kebudayaan dapat merupakan kejahatan ketika terjadi interaksi antar budaya (Mustofa, $2010: 176$ ). 


\section{Cultural Criminology}

Menurut Jeff Ferrell (2001), asumsi awal perkembangan kajian kriminologi budaya sebagai bentuk jawaban atas metodologi penelitian kriminologi yang tidak dapat menjelaskan secara komperehensif mengenai fenomena sosial yang muncul dalam perkembangan budaya kontemporer dan himpitan budaya konformis urban, layaknya budaya streetpunk, hingga budaya geng sepeda motor yang dianggap sebagai bentuk penyimpangan sosial dan di label sebagai "penyakit" sosial yang merugikan. Lebih lanjut ia menjelaskan, kriminologi budaya menggambarkan perspektif dari kajian budaya dengan menggunakan metodologi etnografis dan analisis media/tekstual. Orientasi kajian ini mengarah pada penggambaran, makna representasi bentuk kejahatan serta penangananya. Lebih spesifiknya kajian ini, menginvestigasi kerangka pemikiran atas gaya hidup, dinamika subkultur dan kriminalisasi simbolik sebagai bentuk budaya popular, yang menjadi media penyalur konstruksi atas kejahatan dengan isu pencegahan kejahatan. Area kajian ini dipengaruhi oleh perkembangan media kekinian, kondisi masyarakat dalam melihat kejahatan, media massa dan budayabudaya kebijakan, ruang publik dan emosi yang terjalin secara kolektif dalam membentuk pemahaman terhadap suatu bentuk kejahatan (Robbyansyah, 2011: 345).

Kemudian, penjelasan tentang kriminologi budaya (cultural criminology), Presdee (2000) mengemukakan pentingnya metodologi visual untuk membantu seorang peneliti memahami isu sosial dengan kombinasi penelitian sosial budaya sehingga dapat memberikan analisis dan pemahaman yang luas dalam menjelaskan makna kejahatan dan penyimpangan. Seperti pemahaman seseorang terhadap masyarakat dalam bentuk pengalaman hidup yang muncul dari proses praktek sosial (Jeff Ferrell, 2004).

Lebih lanjut, kajian kriminologi budaya mengeksplorasi berbagai cara dimana kekuatan budaya berkaitan dengan praktek kejahatan dan pengendalian kejahatan pada masyarakat kontemporer. Hal ini menekankan sentralitas makna representasi dan kekuasaan dalam merekonstruksi kejahatan, apakah kejahatan tersebut dibangun sebagai suatu bentuk hiburan atau protes politik sebagai subversi subkultur. Tujuannya untuk memahami kejahatan sebagai aktivitas manusia yang ekspresif dan mengkritik kebijakan yang dirasakan terkait kejahatan politik kontemporer dan sistem peradilan pidana. Dalam kriminologi budaya, akal dan sifat manusia menempati sudut pandang istimewa pada kehidupan sosial sehari-hari. Fokus yang sama tentang kejahatan dan budaya menempatkan perbedaan makna pelanggaran dan posisi itu tepat dimana norma-norma yang dikenakan mengancam hukum dan dapat merusak aturan yang berlaku (Jeff Ferrell K. H., 2008).

Berkaitan tentang fenomena pelanggaran lalu lintas yang dilakukan para pengendara sepeda motor setiap hari di jalan raya Jakarta, merupakan bentuk penurunan moralitas masyarakat, yang mana tidak lagi peduli dengan aturan hukum. Di lain hal, perilaku seperti ini merupakan suatu bentuk kebiasaan yang dibiasakan dan terjadi setiap hari dengan pola yang sama. Kemudian dalam analisis kajian cultural kriminology, fenomena perilaku pengendara sepeda motor dilihat sebagai bentuk kejahatan dan budaya (crime as culture).

\section{Crime As Culture}

Dalam konsep kriminologi budaya kejahatan dan perilaku kriminal merupakan suatu bentuk fenomena budaya yang memiliki hubungan intelektual dengan kriminologi postmodern. Berdasarkan perspektif ini, kejahatan muncul dari berbagai instansi dan lembaga kontrol sosial yang dianggap merekonstruksi budaya itu sendiri. Dalam hal ini kriminologi budaya melibatkan fokus pada makna interaksi di mana aturan-aturan yang dibuat dirusak karena persoalan penurunan moralitas masyarakat (Burke, 2009).

Untuk mendapatkan pemahaman yang lebih jelas mengenai visualisasi perilaku pengendara sepeda motor dilihat sebagai bentuk kejahatan dan budaya (crime as culture). Menurut pemikiran Ferrell dan Sanders (1995) mendefinisikan kejahatan dan budaya dalam kajian kriminologi budaya, dimana eksistensi keberadaannya dalam kehidupan sehari-hari ditujukan pada sejarah kehidupan, musik, kesenian dan termasuk juga tentang bagaimana seseorang bertingkah laku sesuai dengan aturan dan norma yang berlaku di masyarakat.

Berbeda dari tulisan sebelumnya, Gelder \& Thornton (1997: 473-550) menjelaskan tentang kejahatan sebagai budaya adalah mengakui bahwa banyak dari perilaku kriminal di label pada saat perilaku subkultur yang sama, masingmasing di organisir, seperti jaringan simbol, ritual, dan berbagai makna. Dalam subkultur ini dijelaskan seperti kejahatan dalam bentuk konten dan identitas frame gambar. 
Perlu untuk diketahui, berkaitan dengan budaya menyimpang mengutip Rock (2000) istilah penyimpangan atau devience, diartikan sebagai perilaku yang terlarang, perlu dibatasi, disensor, diancam hukuman, atau label lain yang dianggap buruk sehingga istilah tersebut sering dipadankan dengan pelanggaran aturan. Namun, istilah penyimpangan tersebut tetap lebih luas dari pada kriminalitas karena yang menyimpang itu tidak sepenuhnya melanggar secara kriminal (Supardan, 2009:144).

Berbagai bentuk perilaku dan pelanggaran yang dilakukan oleh pengendara sepeda motor maupun pengemudi mobil selama berkendara terjadi setiap hari di jalan raya Jakarta. Berdasarkan hasil penelitian dan analisis dalam tulisan ini, penulis melihat adanya suatu bentuk karakteristik yang melekat dalam diri individu masyarakat, sehingga terbentuk suatu kebiasaan yang dibiasakan, dilakukan berulang-ulang dalam berkatifitas sehari-hari, sehingga menjadi sebuah budaya menyimpang. Fenomena ini dikenal dengan kejahatan dan budaya (crime as culture) yang muncul dalam bentuk rutinitas keseharian individu masyarakat. Fenomena ini juga dilihat sebagai bentuk kejahatan dalam kehidupan sehari-hari (crime in everyday life).

\section{Crime In Everyday Life}

Fenomena perilaku pengendara sepeda motor yang melanggar peraturan lalu lintas dalam hal ini dilihat sebagai bentuk kejahatan dalam kehidupan sehari-hari (crime in everyday life). Perilaku ini dilakukan dalam bentuk kebiasaan yang dibiasakan dan terjadi setiap hari di jalan raya Jakarta. Seperti yang dikemukakan oleh Mustofa (2010:197) kejahatan dalam kehidupan sehari-hari (everyday life crimes) tersebut berada pada kawasan abu-abu, berada antara tindakan yang tidak legal atau tidak bermoral. Masuk dalam kategori ini adalah menerobos lampu lalu lintas yang berwarna merah, mengendarai kendaraan dengan melawan arus. Tindakan tersebut lebih sering dikategorikan sebagai tidak bermoral atau tidak jujur baik oleh pelaku maupun korbannya.

Diperkuat dari tulisan Felson (1998:20) dalam bukunya yang berjudul Crime and Everyday Life menyebutkan bahwa, adanya sebuah kasus khusus dari kekeliruan moralitas ditunjukkan pada keyakinan, bahwa kejahatan dihasilkan karena adanya penurunan moralitas masyarakat. Dalam konteks ini berbicara tentang kebiasaan yang dilakukan oleh para pengendara sepeda motor, terbentuk sebagai perilaku sehari-hari.
Fenomena perilaku pengendara sepeda motor dalam hal ini dapat di gambarkan sebagai bentuk tidak berfungsi dan tidak efektifnya dari aturan moral dan norma-norma kelembagaan yang berlaku di masyarakat yang berkaitan dengan pelanggaran yang dilakukan secara sadar oleh individu masyarakat (Nandan, 1980).

Di lain hal, Durkheim menjelaskan, dalam buku The Division of Labour In Society (1893/1964) menggambarkan keadaan deregulasi (deregulation) di masyarakat, diartikan sebagai tidak ditaatinya aturan-aturan yang terdapat dalam masyarakat, dan orang tidak tahu apa yang diharapkan dari orang lain. Keadaan deregulation atau normlessness ini yang menimbulkan perilaku deviasi. Kemudian, ia juga menjelaskan hubungan antara perkembangan relasi individu dengan masyarakat dan sesuatu yang dilihat sebagai bentuk krisis moralitas (Ritzer, 2011: 88).

Lebih lanjut, Durkheim menjelaskan aspek penting dari konsep anomi menggambarkan tentang "situasi" kekacauan. Kata "anomie" berasal dari bahasa Yunani yaitu anomia, yang berarti pelanggaran hukum atau "Tanpa hukum", dan mengacu pada ketidakstabilan sosial, akibat gangguan dalam nilai, serta perasaan pribadi dari ketidakpastian dan keterasingan (Garfield, 1987).

Secara sederhana, penjelasan dari tulisan tersebut ketika dikaitkan dengan fenomena pelanggaran lalu lintas dan perilaku pengendara motor dapat disimpulkan bahwa persoalan moral yang terjadi di masyarakat dapat di atasi oleh organisasi hukum yang tegas, khususnya fenomena mengenai perilaku pengendara sepeda motor yang berhubungan langsung dengan penegak hukum yakni polisi lalu lintas seharusnya tegas dalam memberikan sanksi kepada para pengendara sepeda motor yang melanggar aturan, seperti melawan arus, tidak memakai helm, menerobos lampu merah, dan berbagai bentuk pelanggaran lalu lintas yang lainnya.

\section{KESIMPULAN DAN SARAN}

\section{Kesimpulan}

Berdasarkan hasil analisis penulis dalam tulisan ini melihat, fenomena pelanggaran lalu lintas yang terjadi setiap hari di jalan raya Jakarta merupakan bentuk perilaku pengendara sepeda motor yang hadir sebagai sebuah kondisi anomi di jalanan, sebagaimana pemahaman anomi dalam konteks ini yaitu demoralisasi, 
yakni terjadinya penurunan moralitas masyarakat yang disebabkan karena melemahnya pengendalian sosial, dimana dalam hal ini kurang efektifnya penegak hukum dalam menindak pelaku pelanggaran lalu lintas setiap hari di jalan raya.

\section{Saran}

Untuk itu saran yang dapat penulis berikan sebagai seorang akademisi dalam karya sederhana ini adalah : besarnya resiko dan dampak yang disebabkan karena melakukan pelanggaran lalu lintas menjadi sebuah catatan penting bagi pihak penegak hukum khususnya kepolisian, dalam hal ini polisi lalu lintas untuk dapat memberikan sanksi tegas terhadap pengendara yang tidak disiplin dalam berlalu lintas, sehingga masyarakat khususnya pengendara sepeda motor, paham akan pentingnya menjaga keselamatan diri dalam berkendara dengan menciptakan budaya tertib dan disiplin dalam berlalu lintas. Kemudian karena perilaku pengendara sepeda motor berkaitan dengan persoalan moralitas masyarakat, dimana terjadinya penurunan dan pengamalan terhadap nilai-nilai, norma dan moralitas yang berlaku dalam kehidupan seharihari, maka perlu kiranya untuk merefleksi kembali sistem pendidikan dan memasukkan pembelajaran mengenai kedisiplinan dan penerapan moralitas mulai dari tingkat sekolah dasar, sampai ke tingkat perguruan tinggi, agar bisa di aktualisasikan dengan baik.

\section{DAFTAR PUSTAKA}

\section{Buku :}

Adang. Yesmil Anwar, 2010, Kriminologi, PT. Refika Aditama, Bandung.

Bellah, R. N. (1973). Emile Durkheim On Morality And Society. Chicago And London: The University Of Chicago Press.

Burke, R. H. (2009). An Introduction to Criminological Theory. USA and Canada.

Clinard, Marshall.B (1985). Sociology of Deviant Behavior. United Stated of America.

Creswell, Jhon W, 2010, Research Design (Pendekatan Kualitatif, Kuantitatif dan Mixed), Penerbit Pustaka Pelajar, Yogyakarta.
Darmawan, Moh. Kemal,2000, Materi Pokok Teori Kriminologi. Universitas Terbuka, Jakarta.

2013,Memahami Strategi Pencegahan Kejahatan. Departemen Kriminologi Fisip UI, Jakarta.

Deflem, M. (2008). Sociology of Law Visions of a Scholarly Tradition. Cambridge, New York, Melbourne,Madrid, Cape Town, Singapore, Sao Paulo: Cambridge University Press.

Durham, William H. (1991). Coevolution: Genes culture, and human diversity. Stanford: Stanford University Press.

Felson, M. (1998). Crime and Everyday Life. Pine Forge Press, Thousand Oaks,London, New Delhi.

Garfield, E. (1987). The Anomie-Deviant Behavior Connection: The Theories of Durkheim, Merton, and Srole. Essays of an Information Scientist, 272.

Gelder K, Thornton S, eds. 1997. The Subcultures Reader. London: Routledge

Hagan, J. (1987). Modern Criminology, Crime, Criminal Behaviour, and its Control. University of Toronto: McGraw Hill Book Company.

Harris, M. (1999). Theories of Culture in Postmodern Times. London and New Delhi.

Jeff Ferrell, K. H. (2004). Cultural Criminology Unleashed. London.

Jeff Ferrell, K. H. (2008). Cultural Criminology. London.

Koentjaraningrat, 1985, Pengantar Ilmu Antropologi, Penerbit Aksara Baru, Jakarta.

Lawang. M. Z. Robert, 1988, Teori Sosiologi Klasik dan Modern, Penerbit PT. Gramedia, Jakarta.

Meliala, Adrianus Eliasta, 2011, Viktimologi: Bunga Rampai Kajian Tentang Korban Kejahatan. Fisip UI Press, Depok.

Mustofa, Muhammad. 2005, Metodologi Penelitian Kriminologi, Fisip UI Press, Depok. 
2010, Kriminologi Edisi Kedua Kajian Sosiologi Terhadap Kriminalitas, Perilaku Menyimpang dan Pelanggaran Hukum, Penerbit Sari Ilmu Pratama (SIP), Bekasi.

Nandan, Y. (1980). Emile Durkheim: Contributions to L'Annee Sociologique. London: Collier Macmillan Publishers.

Nisbet, R. A. (1965). Emile Durkheim. Makers of Modern Social Science, 9.

Presdee, M. (2000). Cultural Criminology and The Carnival of Crime. London and New York.

Ritzer, George dan Douglas J. Goodman, 2011, Teori Sosiologi, Penerbit Kreasi Wacana, Bantul.

Schmaus, W. (2004). Rethinking Durkheim and His Tradition. Cambridge, New York.

Simpson, G. (2002). Emile Durkheim Suicide A Study in Sociology. London and New York: This edition published in the Taylor \& Francis e-Library.

Smith, J. C. (2005). The Cambridge Companion To Durkheim. Cambridge, New York, Melbourne, Madrid, Cape Town, Singapore, $\mathrm{S}^{\sim}$ ao Paulo: Printed in the United Kingdom at the University Press, Cambridge, 213.

Soekanto, Soerjono, 1984, Teori Sosiologi Tentang Perubahan Sosial, Penerbit Ghalia Indonesia, Jakarta.

Soekanto, Soerjono, 1990, Sosiologi Suatu Pengantar, Rajawali Pers, Jakarta.

Sugiyono, 2010, Metode Penelitian Pendidikan (Pendekatan Kuantitatif, Kualitatif, dan $R \& D)$, Penerbit CV. Alfabeta, Bandung.

Supardan, Dadang. 2009, Pengantar Ilmu Sosial Sebuah Kajian Pendekatan Struktural, Penerbit PT.Bumi Aksara, Jakarta.

Thompson, K. (1985). Readings From Emile Durkheim. London and New York: Faculty of Social Science, The Open University Milton Keynes, 44.

Tjahjono, Tri, 2011, Analisis Keselamatan Lalu Lintas Jalan, Penerbit CV. Lubuk Agung, Bandung.
Wolff, K. H. (1960). Essay On Sociology And Philosophy. New York, Evanston, and London.

\section{Jurnal Ilmiah:}

Adilla, Nissa. (2009). Pengaruh Kontrol Sosial Terhadap Perilaku Bullying Pelajar di Sekolah Menengah Pertama. The Indonesia Journal of Criminology, 57.

Bernburg, T. T. (2004). Durkheim's Theory of Social Order and Deviance: A Multi-Level Test. European Sociological Review, 271285.

Dahl, R. (2005). Environmental Health Perspectives. Heavy Traffic Ahead: Car Culture Accelerates, 238.

Durie, A. C. (1969). Roads And Traffic Problems. Journal of the Royal Society of Arts, 345-360.

Eray, V. Y. (2004). Social Behavior and Personality. Sociely for Pcrsonalily Research, 791-796.

Ferrell, J. (1999). Annual Review of Sociology. Cultural Criminology, 395-418.

Greek, D. C. (2005). Visual Criminology: Using Photography as an Ethnographic Research Method in Criminal Justice Settings. School of Criminology and Criminal Justice Florida State University, 2-10.

Greenwald, R. (1968). Scientific Evidence in Traffic Cases. The Journal of Criminal Law, Criminology, and Police Science, 57-73.

Herman, R. (1992). Operations Research. echnology, Human Interaction, and Complexity: Reflections on Vehicular Traffic Science, 199-200

Kelcey, G. (1927). Traffic Regulations to Prevent Accidents and to Expedite Fluid Traffic Movement: AnAnalysis of Accident Causes and Some Suggestions for Their Correction. Annals of the American Academy of Political and Social Science, 161-171.

Marske, C. E. (1987). Durkheim's "Cult of the Individual" and the Moral Reconstitution of Society. Sociological Theory, 1-14. 
Mawson, A. R. (1970). Durkheim and Contemporary Social Pathology. The British Journal of Sociology, 298-313.

McCloskey, D. (1976). On Durkheim, Anomie, and the Modern Crisis. American Journal of Sociology, 1481-1488.

Mellor, C. S. (1998). Durkheim, Morality and Modernity: Collective Effervescence, Homo Duplex and the Sources of Moral Action. The British Journal of Sociology, 193-209.

Nancy J. Herman, P. L. (1999). Road Rage: An Exploratory Analysis. Michigan Sociological Review, 65-79.

Olsen, M. E. (1965). Durkheim's Two Concepts of Anomie. The Sociological Quarterly, 3744.

Robbyansyah, Muhamad. (2011). Sebuah Kajian Cultural Criminology Atas Moshing di dalam Konser Underground. The Indonesian Journal of Criminology, 345.

Rose, S. E. (1924). Traffic Violations and the Court - Detroit's Violation Bureau. Annals of the American Academy of Political and Social Science, 185-190.

Ross, H. L. (1960-1961). Traffic Law Violation: A Folk Crime. Social Problems, 231-241.

Rundmo, H. I. (2004). Norwegian University of Science and Technology, Trondheim, Norway. Attitudes towards traffic safety, driving behaviour and accident, 555 - 572.

Vaughn, L. M. (2011). Visual Anthropology. University of Cincinnati College of Medicine/Cincinnati Children's Hospital Medical Center, 906.

Williamson, A. (1999). Young Drivers and Crashes. Summary paper prepared for Motor Accidents Authority, 2.

\section{Dokumentasi :}

Undang-undang No 22 Tahun 2009 Tentang Lalu Lintas

http://www.tribunnews.com//28 Januari 2014

http://www.tertiblantas.com

http://www.tribunnews.com/nasional/2014/01/2 6/jumlah-korban-tewas-akibat-kecelakaanlalu-lintas-tahun-2013-menurun.

http://motor.otomotifnet.com/read/2013/12/02/3 45833/122/14/Sepanjang-2013-616-OrangMeninggal-Karena-Kecelakaan-di-JalananJakarta.

http://indonesiarayanews.com/read/2013/12/27/ 91282/2013-korban-tewas-kecelakaan-lalulintas-capai-668-orang.

http://www.tempo.co/read/news/2014/01/23/063 547539/Kecelakaan-Penyebab-UtamaKematian-Remaja.

http://otomotif.kompas.com/read/2013/02/26/68 19/94.2.juta.Mobil.dan.Sepeda.Motor.Bersel iweran.di.Jalanan.Indonesia

http://otomotif.blogekstra.com/ardierawk/lainlain/indonesia-akan-jadi-tempat-sampahotomotif.html

http://www.merdeka.com/peristiwa/nadiempelanggan-ojek-yang-sukses-kembangkanbisnis-go-jek.html

http://news.detik.com/read/2014/05/14/075600/ 2581936/10/tak-disiplinnya-pemotor-dijakarta-ini-daftar-jalan-yang-digunakanpara-pelawan-arus? 